\title{
IMPROVING ENGLISH VOCABULARY MASTERY BY USING CROSSWORD PUZZLE
}

\author{
Wina Halimatus Sadiyah ${ }^{1}$, Wina Septiani ${ }^{2}$, Evie Kareviati ${ }^{3}$ \\ ${ }^{1}$ IKIP SILIWANGI \\ 2 IKIP SILIWANGI \\ ${ }^{3}$ IKIP SILIWANGI \\ ${ }^{1}$ winahalimatuss16@gmail.com, ${ }^{2}$ winaaseptiani911@gmail.com, ${ }^{3}$ akhmadjaelani91@yahoo.co.id
}

\begin{abstract}
Vocabulary is important in English language. Because, to make a sentence an adequate vocabulary is needed. So, the researcher apply a method in the classroom which can make students motivated to learn vocabulary. The aim of the research is to know that the crossword puzzle is effective to improve students' vocabulary or not through the use of crossword puzzles among seventh-grade students of MTs At-Taqwa Cihampelas in the academic year of 2018/2019. The method used in this research is quantitative technique and the pre-experimental research design conducted in one class. The population in this research is seventh-grade students of MTs At-Taqwa Cihampelas with the total number of the population are 104 students consisting of 3 classes, and the sample is class VII.A that consist of 30 students. The data is collected with the pretest and posttest as an instrument. The researcher conducted the tests before (pre-test) and after (post-test). After that the researcher give students a treatment consists of five meetings. The result show that the mean score of pre-test was 41.83 , and the post-test was 75.67 after gives treatment uses crossword puzzle. It means that teaching English vocabulary using a crossword puzzle was effective media to improve students' vocabulary at seventhgrade.
\end{abstract}

Keywords: crossword puzzle, students' vocabulary mastery

\section{INTRODUCTION}

Teaching English is needed for preparing the globalization era and developing science. So, we can increase competition with the world community. To master all, they should prepare them self with vocabularies. The vocabulary an important thing in learning English. If the students have a lack of vocabulary, they cannot express their ideas, and it is impossible to communicate effectively among people.

Vocabulary is one of the language component that support the student in learning language. According to Richard (2001:4) in Anwar and Efransyah (2018) vocabulary is one of the most obvious components of language and one of the first things applied linguists turned their attention to. Murcia (2001: 285) in Parmawati statest that vocabulary learning is central to language acquisition, whether the language is first, second or foreign. If people could be mastered vocabulary well, they will speak, listen, read and write. various ways are done to manipulate the vocabulary that aims to improve the ability of writers and speakers to make emotive effects and construct a smooth and coherent of the discourse

The students' vocabulary mastery needs improvement. Case (1994: 5) in Profita, Susilohadi and Sarosa claims that puzzle are useful for language learners because the enjoyment, 
satisfaction, reflection, and play can focus learners attention on the language in a concentrated but nonstressful way. So, the researcher brings the way of teaching vocabulary by using crossword puzzles, to improving students' vocabulary mastery.

According to Widyasari in Anwar Taofik Yayang and Efransyah (2018) there are some kinds of crossword puzzles that can be performed in the process of teaching and learning vocabulary in the classroom using crossword puzzle game, those are:

a. Oral Puzzle. It is a puzzle that is giving oral by teachers, and students are given only an empty crossword puzzles without a clue. Give instructions orally can train hearing students. Tell students to fill out what they could and then repeat the instructions again until they understand.

b. Picture Puzzle. It is a puzzle using the picture as a clue. And only give the students the puzzle without the clues. For each clue, replaced with pictures. It works very well with a unit which embroiled many new vocabulary.

c. Object Puzzle. It is the crossword where inside the object is written a clue. give a blank puzzle without a hint to the student. The goods placed around the room, each given a labeled with the prompts number. Then the students are asked to go around at different stations; allow them to pick up the objects as they complete the puzzle.

According to Plaister in in Anwar Taofik Yayang and Efransyah (2018) in teaching vocabulary there are some advantage of crossword puzzle that can be taken, namely:

1. Learning vocabulary by doing, because doing action would be more meaningful and motivating students.

2. By doing puzzle, students are trained to involve in the problem solving.

3. It is interesting and challenging for students. It can avoid students' boredom of monotonous learning. In this case, puzzle tries to increase students' attention, their lesson materials and this procedure better learning.

4. The puzzle in group or classroom discussion students is trained to be more critical thinking.

5. The puzzle in group will make the students feel fun, enjoy in their learning English. This is and helpful for students' in learning English.

Based on the statement above, the researcher indicate that crossword puzzle is good way to improving vocabulary.

\section{METHOD}

This research about improving English vocabulary mastery by using crossword puzzle in the seventh grade at MTs At-Taqwa Cihampelas. The aim of the research is to know that the crossword puzzle is effective to improve students' vocabulary or not. The researcher will employ the quantitative method and the pre-experimental research design conducted in one class. The population in this research is seventh-grade students of MTs At-Taqwa Cihampelas with the total number of the population are 104 students consisting of 3 classes, and the sample is class VII.A that consist of 30 students. The data is collected with the pretest and posttest as an instrument. 


\section{RESULTS AND DISCUSSION}

\section{Results}

In this section the researcher using SPSS version 15.0 to answer whether crossword puzzle is effective to improve students' vocabulary at the seventh-grade of MTs At-Taqwa Cihampelas, with the title below:

Table 1. The Result of Pretest and Posttest

\begin{tabular}{|c|c|c|c|}
\hline No & Name & Pretest & Postest \\
\hline 1 & Student 1 & 26 & 70 \\
\hline 2 & Student 2 & 66 & 95 \\
\hline 3 & Student 3 & 59 & 65 \\
\hline 4 & Student 4 & 56 & 90 \\
\hline 5 & Student 5 & 20 & 70 \\
\hline 6 & Student 6 & 25 & 75 \\
\hline 7 & Student 7 & 40 & 75 \\
\hline 8 & Student 8 & 15 & 55 \\
\hline 9 & Student 9 & 30 & 60 \\
\hline 10 & Student 10 & 59 & 70 \\
\hline 11 & Student 11 & 26 & 70 \\
\hline 12 & Student 12 & 20 & 70 \\
\hline 13 & Student 13 & 30 & 55 \\
\hline 14 & Student 14 & 40 & 80 \\
\hline 15 & Student 15 & 40 & 70 \\
\hline 16 & Student 16 & 40 & 85 \\
\hline 17 & Student 17 & 55 & 70 \\
\hline 18 & Student 18 & 20 & 60 \\
\hline 19 & Student 19 & 35 & 75 \\
\hline 20 & Student 20 & 20 & 80 \\
\hline 21 & Student 21 & 45 & 70 \\
\hline 22 & Student 22 & 55 & 90 \\
\hline 23 & Student 23 & 30 & 95 \\
\hline 24 & Student 24 & 70 & 90 \\
\hline 25 & Student 25 & 70 & 80 \\
\hline 26 & Student 26 & 55 & 90 \\
\hline 27 & Student 27 & 60 & 90 \\
\hline 28 & Student 28 & 40 & 80 \\
\hline 29 & Student 29 & 40 & 85 \\
\hline 30 & Student 30 & 70 & 90 \\
\hline
\end{tabular}


Table 2. Tests of Normality

\begin{tabular}{|ll|r|r|r|r|r|r|}
\hline & \multicolumn{4}{|c|}{ Kolmogorov-Smirnov(a) } & \multicolumn{3}{c|}{ Shapiro-Wilk } \\
\cline { 3 - 8 } & kelas & Statistic & Df & \multicolumn{1}{c|}{ Sig. } & Statistic & \multicolumn{1}{c|}{ df } & Sig. \\
\hline pretest & pretest & .145 & 30 & .110 & .930 & 30 & .050 \\
& postest & .150 & 30 & .082 & .938 & 30 & .083 \\
\hline
\end{tabular}

a Lilliefors Significance Correction

\section{Criteria:}

If Sig $>0.05$

The sample was a normal distribution.

Pretest: $\quad$ Sig $0.110>0.05$

Posttest: $\quad$ Sig $0.82>0.05$

The sample was a normal distribution

We look to Kolmogorov-Smirnov because the sample is less than 33 .

Table 3. Paired Samples Statistics

\begin{tabular}{|ll|r|r|r|r|}
\hline & & & & \\
& & Mean & $N$ & Std. Deviation & Std. Error Mean \\
\hline Pair 1 & Pretest & 41.83 & 30 & 17.201 & 3.140 \\
& Posttest & 76.67 & 30 & 11.621 & 2.122 \\
\hline
\end{tabular}

At this output, we are shown the data of statistics from the sample pretest and posttest. The mean of pretest 41.83 and the mean of posttest 76.67 it means that score improved from using crossword puzzle.

Table 4. Paired Samples Test

\begin{tabular}{|c|c|c|c|c|c|c|c|c|}
\hline & \multicolumn{5}{|c|}{ Paired Differences } & \multirow{3}{*}{$\begin{array}{c}\mathrm{T} \\
\text { Mean } \\
\text { Upper }\end{array}$} & \multirow{3}{*}{$\begin{array}{c}\text { df } \\
\begin{array}{c}\text { Std. } \\
\text { Deviatio } \\
n\end{array} \\
\text { Lower }\end{array}$} & \multirow{3}{*}{$\begin{array}{c}\begin{array}{c}\text { Sig. (2- } \\
\text { tailed) }\end{array} \\
\begin{array}{c}\text { Std. Error } \\
\text { Mean }\end{array} \\
\text { Upper }\end{array}$} \\
\hline & \multirow{2}{*}{ Mean } & \multirow{2}{*}{$\begin{array}{c}\begin{array}{c}\text { Std. } \\
\text { Deviation }\end{array} \\
\text { Upper }\end{array}$} & \multirow{2}{*}{$\begin{array}{l}\text { Std. } \\
\text { Error } \\
\text { Mean } \\
\text { Lower }\end{array}$} & \multicolumn{2}{|c|}{$\begin{array}{l}95 \% \text { Confidence } \\
\text { Interval of the } \\
\text { Difference }\end{array}$} & & & \\
\hline & & & & Upper & Lower & & & \\
\hline $\begin{array}{ll}\text { Pair } & \text { pretest - } \\
1 & \text { posttest }\end{array}$ & -34.833 & 14.300 & 2.611 & -40.173 & $29.494^{-}$ & -13.342 & 29 & .000 \\
\hline
\end{tabular}

Criteria: If $\mathrm{Sig}>0.05 \mathrm{H} 0$ is accepted

If Sig. $<0.05 \mathrm{H} 0$ is rejected

The result Sig. $0.000<0.005$ so, the null hypothesis was rejected and the alternative hypothesis was accepted.

\section{Discussion}

In this research, the researcher using quantitative method and pre-experimental research, who consists of 30 students at seventh-grade in Mts At-Taqwa Cihampelas. The researcher uses pretest and posttest, consists of 7 meetings. First, pretest before the researcher gives treatment, second is treatment consists of five meetings, and the last is posttest after the researcher gives treatment. Based on the result the researcher indicates that the use of crossword puzzle is effective to improve students vocabulary in seventh-grade of Mts At-Taqwa Cihampelas. The data shows that the use of crossword puzzles may have contributed to the improvement of performance since at the pretest. Based on the table 3 , the mean score of pretest 41.83 and after 
apply a crossword puzzle the mean of posttest 76.67. It means that crossword puzzle can improve students vocabulary.

\section{CONCLUSION}

The aim of the research is to know that the crossword puzzle is effective to improve students' vocabulary or not, with using a quantitative method and the pre-experimental research design conducted in one class. The sample was a normal distribution. Based on the data statistics above, result of the research show that the improvement of students' vocabulary mastery could be seen in the increasing of mean score of pretest 41.83 and the mean of posttest 76.67. The last, the result Sig. $0.000<0.005$. So, the null hypothesis was rejected and the alternative hypothesis was accepted. It means that score was improve from using crossword puzzle at the seventhgrade students of MTs At-TAqwa Cihampelas. From the statements, it can be concluded that the crossword puzzle is able to improve the students' vocabulary.

\section{ACKNOWLEDGMENTS}

Alhamdulillahirabbil 'alamin. Praise to Allah SWT who has enabled the researcher to finish this paper. Peace and salutation for Rasulullah SAW. Thanks to parents, family and our lectures during completing the paper the researcher obtained many help, motivations, and suggestions.

\section{REFERENCES}

Aseptiana Parmawati. (2018). Using Magic Sentences Technique to Improve Students Vocabulary. Lingual Jorunal Udayana Bali, 6(November), 28.

Dini Restu Profita, Gunarso Susilohadi, T. S. (2012). IMPROVING ENGLISH VOCABULARY MASTERY BY USING CROSSWORD PUZZLE.

Nurul Puspita , N. S. (2017). Teaching Vocabulary by Using Crossword Puzzle.

Restu Anggi Winita, F. S. R. (2018). TEACHING ENGLISH VOCABULARY USING

PICTURE IN EIGHTH GRADE OF JUNIOR HIGH SCHOOL.

Yayang Taofik Anwar, E. (2018). TEACHING ENGLISH VOCABULARY USING CROSSWORD PUZZLE GAME AT THE SEVENTH GRADE STUDENTS. 